of control in the light of current biological knowledge of this species are discussed in some detail. A considerable amount of information is now available on the epidemiology of rabies in Europe, where the red fox is also the principal vector, and this is summarised. At the end consideration is given to the part that other species play in the carriage and transmission of this disease elsewhere in the world.

The study provides an excellent example of an emerging branch of animal science, that of veterinary ecology, where attention to the details of many other aspects of the biology of a particular species can provide a much more meaningful overview of the natural history of a disease process than that provided simply by a laboratory study of the pathological effects of a potentially infectious organism. This excellent little book should be compulsory reading for anybody who might have responsibility for coping with a rabies outbreak in Britain, and for those whose work in other countries may bring them into contact with wildlife vectors of the disease.

D.M. JONES

\title{
Shillay and the Seals, by Robert Atkinson. Collins Harvill, £6.95.
}

This is a highly personal account of one man's journey by boat through the many islands which make up the Outer Hebrides - islands with names that roll off the tongue, such as Berneray, Pabbay, Gasker, Haskeir and Shillay. In it may be found descriptions of all the facets which make up their haunting beauty - scenery, weather which can turn at whim into lashing fury, social history and, above all, wildlife. Here is a paradise for naturalists with 'sweet smelling flowery machair', rocky and remote cliffs and sandy inlets harbouring arctic terns, fulmars, storm and Leach's petrels, and puffins.

However, it was the attraction of grey seals which led the author to spend a solitary autumn on the island of Shillay observing and photographing them as they hauled ashore for the breeding season. He stayed for the complete cycle of courting, mating, birth of and suckling of young, and until the pups moulted and learnt to swim. His account is fascinating, often amusing and above all intimate. The inclement weather during his vigil makes the reader realise what incredibly lonely places these islands can be and the influence it can have on the grey seal population in terms of pup mortality. The text is spiced with historical references to grey seals by such naturalists as Harvie Brown and Fraser Darling, and by ships' captains sent to chart the islands in the last century. Something of the intractable problems facing the remaining inhabitants of some of the islands are also given, resulting in a very readable and evocative book.

SUSAN JOY

\section{Half of Paradise, by David Bellamy. Cassell, $£ 7.95$.}

This is an account of two Joint Services underwater expeditions to the Chagos Archipelago in 1972 and 1975. Their aim, in addition to training, was to unravel some of the problems of reef formation and growth, and to study the islands' flora and fauna. The first expedition was to the Egmont group; the second to Eagle, Nelson, Four Brothers and Danger.

In an area thought to be poor in reef-forming corals, over 50 genera were found. The most interesting and puzzling discovery was that the most active coral growth is along the most sheltered side of the Great Chagos Bank. The Bank is a giant coral atoll with its extant islands along the north and north-west margins. This growth in sheltered areas is contrary to accepted theory that reef growth is most active on the more exposed, turbulent and well-oxygenated side. Dr Bellamy explains the processes and problems of reef formation very clearly, and his discussions of them are by far the best part of the book.

Faunistically the seabird populations attracted most attention. Six species of tern, three boobies, two shearwaters and two frigates made up the bulk of the populations. 
Unfortunately, because of the abundance of man-introduced rats, only just over 400 of the total of 2450 acres of island are available for birds. Dr Bellamy concludes with a plea for the elimination of the rats and an international agreement to make the whole of the Chagos Bank a nature reserve. He has certainly provided sufficient evidence to justify his proposals.

The book is generally well produced, with attractive layout and plenty of pictures, marred only by Dr Bellamy's rather ponderous humour, especially evident in picture captions; his message is clear enough without this jokiness. It is a pity, too, that he and the editors did not take the trouble to ensure that some of the more tortuous paragraphs were clarified. But it is a book with a worthy aim, and contains a great deal of interest to specialist and non-specialist alike.

S.R.J. WOODELL

\section{Harpooned, by Bill Spence. Conway Maritime Press, £9.50.}

Development in Britain's whaling industry before the end of the 18th century resembles nothing so much as the current plight of British Leyland. Early production was abysmally low, largely through incompetent management, and foreign competitors were thriving, especially the Dutch, who also hogged the best whaling grounds. The British Government helped by slapping heavy taxes on foreign whale product imports and offering bounties to the British, but when our chaps finally got their strategy right they were beaten up by the French navy, the two countries by then being at war. Now, of course, Japan and Russia lead the field and everyone else is trying to stop them.

All this, and what came before, between and after, has been remarkably well researched by Bill Spence. In a highly readable fashion he tells the story of commercial whaling from the 12 th century to the middle of the 20th; of successive depletion of whale populations; and of successive leaders in the industry - Spain, Holland, Great Britain, America, Norway and now Japan. I always like the extra little 'throw-away' snippets in books like this, that bring history to life. It was news to me, for example, that the three ships from which tea was thrown overboard in Boston, 1772, had been brimming with whale oil in their previous voyage, which could have put a new complexion on the Boston Tea Party.

If the title suggests a text about whales it is misleading; this is about the anatomy and incipient extinction of an industry.

JON BARZDO

\section{A Field Guide to the Land Snails of Britain and North-West Europe, by M.P. Kerney and R.A.D. Cameron. Collins, £5.50.}

In the heyday of malacology, over a century ago, a number of well-illustrated books were available for the enthusiastic amateur; today this is not so, and this volume fills the gap. All 279 species occurring in the area are described, and most are illustrated. Gordon Riley's illustrations are meticulous and - to a non-specialist such as myself adequate for identifying most species, with the help of the text. The colour plates are far less pleasing than the line drawings, the colours seeming a little bleached; in trying to give the slugs (and snails) a wet slimy appearance he (or the publisher) has lost the richness of colour of some - Arion ater the familiar $10-\mathrm{cm}$ black or orange slug is a pale ghost of its real self.

Collins has also departed from normal field guide style by including dissections. Admittedly some species are difficult to identify, but it seems a little outside the scope of a field guide, as does the micro-structure of the shell, which needs a binocular microscope to observe. Perhaps this is merely a criticism of the title, since the important thing is to identify the slugs and snails! The maps, covering 276 species, with the British species mapped in even greater detail, are particularly instructive and useful. In 